\title{
Research on the Path to Promote the High-quality Development of China's Trade from the Perspective of Major Trading Partners
}

\author{
Shurui Liu \\ Faculty of International Trade, Shanxi University of Finance and Economics, Wucheng Road, Shanxi, China
}

Keywords: Downward trade; Belt and Road Initiative; Neighboring countries; Free trade zone agreements; the level of institution building

\begin{abstract}
Global trade is weak in 2019, and China faces increasing pressure to stabilize foreign trade. Because of this, the "Guiding Opinions of the CPC Central Committee and the State Council on Promoting the Development of High-Quality Trade" (from now on referred to as "Opinions") was officially announced on November 28. Based on the content of the "Opinions," this article proposes the following strategies starting from China's main trading partners: investing foreign trade in developing countries and emerging economies, and using the "Belt and Road" initiative to achieve growth in trade with countries along the route; The expansion of national trade scale, taking China, Japan, and South Korea as examples, discusses the significance of the expansion of trade scale of neighboring countries from the two aspects of necessity and feasibility for China to cope with global and economic difficulties in economic development; The construction of the trade zone will increase its influence in the foreign trade system. However, in the context of the current complicated trade field, China's trade field faces many risks. Therefore, the last part of the article proposes that from the perspective of the Chinese government, the government should improve the level of system construction, strengthen the ability to control risks, and effectively provide institutional guarantee for Chinese enterprises to go global and the high-quality development of China's trade.
\end{abstract}

\section{Introduction}

On November 28, 2019, the "Guiding Opinions of the Central Committee of the Communist Party of China and the State Council on Promoting the Development of High-Quality Trade" (from now on referred to as "Opinions") was officially announced. This is the comprehensive deployment of the Chinese economy by the Chinese government when it is facing tremendous downward pressure on the world economy and the Chinese economy urgently needs to "stabilize foreign trade." Based on the content of the "Opinions," this article proposes a path for China to develop high-quality trade from the perspective of its main trading partners [1].

Chinese companies have a high market share in advanced economies. In the global economic cold winter, China needs to cultivate new growth points in foreign trade-developing countries and emerging markets. This is a realistic requirement for development in the trade field and a perfect fit for China's "Belt and Road" initiative. At the same time, China's traditional fields and new formats should be integrated to resolve bottlenecks in the development of traditional fields and expand exports. Besides, expanding trade with neighboring countries is equally necessary and feasible. China's neighboring trading partners are mainly Japan and South Korea, India and ASEAN countries. Because of the RCEP's substantial results in 2019, this article uses China, Japan, and South Korea as an example to explore the path of expanding trade between China and Japan and South Korea. At the same time, drawing on the experience of developed countries, the article argues that China should also establish free trade zones with significant world economies, which is of considerable significance to China's right to speak in the trading system [2-3].

Finally, the article considers that in addition to actively exploring new paths for trade development, strengthening risk prevention is also an essential link. From the perspective of the Chinese government, the article proposes that the level of Chinese government system construction should be improved, which directly determines the Chinese government's ability to control risks. 
Risk prevention in the trade field is a powerful guarantee for the high-quality development path of China's trade proposed in the article.

In today's complicated international situation, faced with many uncertainties and instability forces, China should adhere to the comprehensive implementation of the "Belt and Road" strategy, adhere to the establishment of an excellent surrounding development environment, adhere to dialogue with significant world economies, and close economic and trade cooperation, Persist in enhancing the voice and influence of the economic and trade system, persist in comprehensively improving the ability to prevent risks in the economic and trade field, provide the world with Chinese solutions, and contribute to China's strength [4-5].

\section{Analysis of the Current Situation of Global Trade}

Intensifying downward pressure on the world economy in 2019, and many negative factors have combined, leading to a weakening of global trade. Economic aspects: Unilateral trade and protectionist trade forces have increased significantly, trade frictions between major countries have escalated, and non-tariff measures have increased significantly. Political aspects: Geopolitical tensions continue to escalate, Brexit's increasing uncertainty and other factors have caused the cross-effects, which has led to world trade falling into a dilemma.

First, trade growth has slowed significantly. The WTO report shows that the container transport, car product index, international air freight, electronic components, export orders, and agricultural raw materials index of the barometer of goods trade are all below the trend level, and some indexes are even close to the lowest level of the financial crisis and are expected to Continued weakness. In terms of trade in services: most sub-indices have fallen, showing insufficient growth and active resistance. Besides, according to the report of the United Nations Trade Development Commission, global trade is stagnant in 2019. Since 2018, the global maritime transportation has lost its growth momentum, and the maritime trade volume has only increased by $2.7 \%$, which is much lower than the $4.7 \%$ in 2017 , and the port container transportation volume has increased by $4.7 \%$, a year-onyear decrease of two percentage points. In short, various indicators of global economic and trade in 2019 show that trade growth has slowed [6].

Second, many factors have dragged down trade trends. The trade war provoked by the United States has weighed on global trade. The Sino-US trade war is undoubtedly an essential factor influencing the world economy in recent years. The United States and China are the world's first and second-largest economies, so the trade friction between China and the United States is undoubtedly a tsunami for the world economy. As the world's largest economy, the United States wields a big stick of tariffs and trade penalties. It artificially creates and exacerbates trade tensions, creating many uncertain factors for the global trade situation, which has led to a significant slowdown in global trade. Unilateral and protectionist forces have weakened the standard multilateral trading system. In 2019, the United States withdraws or threatens to withdraw from some international treaties and international organizations, or set up obstacles to crack down on multilateral trade, which objectively weakens the global role of the multilateral trading system; hinders the launch of the WTO appeals body member selection process and seriously undermines international trade Dispute resolution rules and order. The international political situation is not very peaceful. Besides, more non-tariff measures have surged to more than 50,000 in 2019, and their unique concealment and diversity have affected about $90 \%$ of global trade.

In summary, under the veil of fog, the complexity of the global trade situation has intensified. How China can cultivate new advantages in trade competition to achieve the goal of "stabilizing foreign trade" has become a new topic. This article looks at China's major trading partners, such as the countries along the "Belt and Road" and neighboring economies, and discusses where China 's trade should be strengthened to cope with the current economic situation and cultivate new momentum for foreign trade development. 


\section{Expand Trade with Countries Along The "Belt And Road."}

Three of the top four of China's major trading partners are developed economies. According to data from the International Bureau of Statistics, from 2009 to 2018, China-Japan, China-US, and China-EU bilateral import and export trade volume remained at the same level as China's total global trade about 30\% (see Table 1). However, in the context of the overall slowdown of the global economy, the economic growth of advanced economies is still insufficient, and the development of Chinese enterprises in advanced economies is even less optimistic. Moreover, the market saturation of Chinese export commodities in developed economies has reached a certain level. Therefore, Chinese companies should no longer focus on export operations in these countries and regions but should cultivate new markets. China should also cultivate new export markets. The point of economic growth [7].

Table 1 China-Japan, China-Europe, China-US Total Imports and Exports from 2009 to 2018

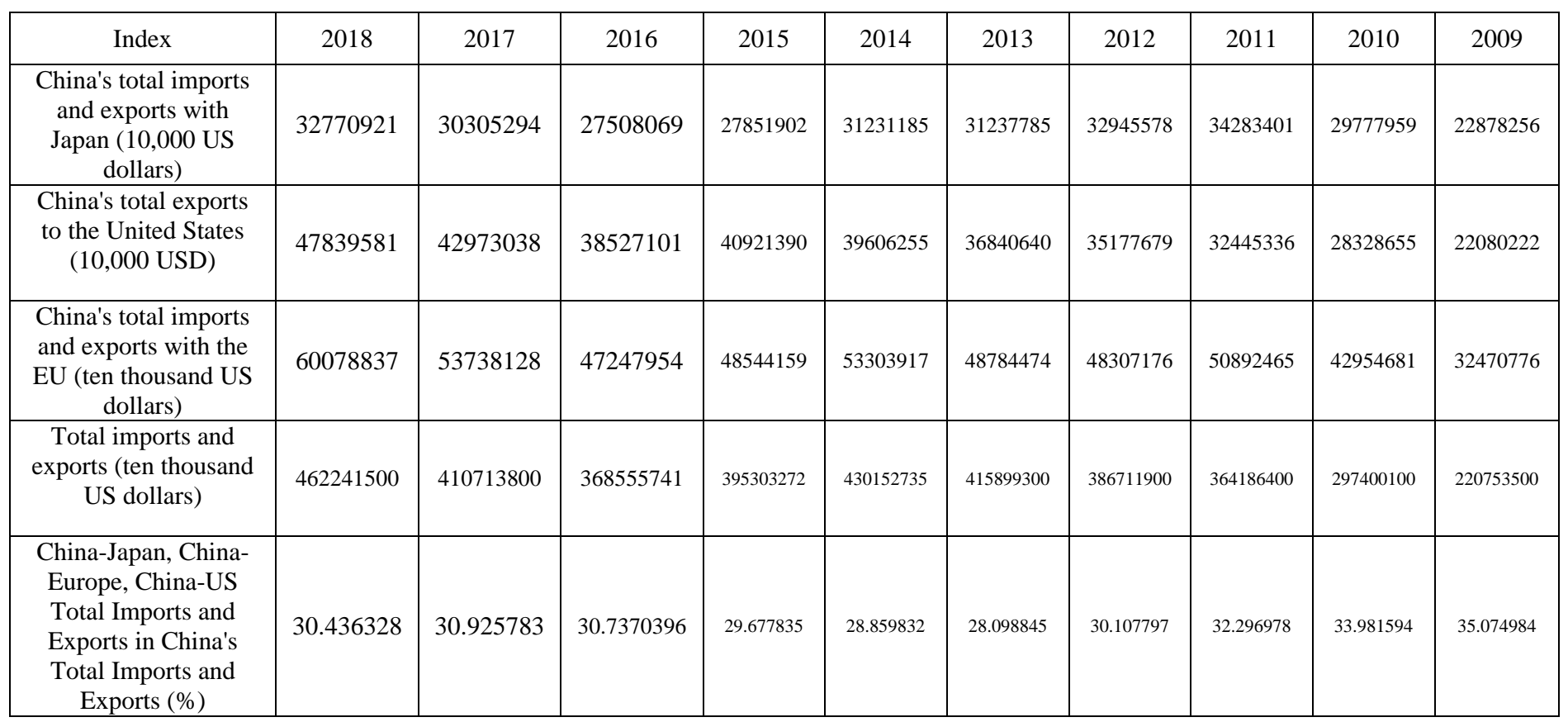

Most of the countries along the "Belt and Road" are developing countries and emerging economies with huge market potential, diversified investment fields, and substantial economic growth space. They are ideal choices for China's import and export trade. Moreover, the "Belt and Road" has a wide range of radiation. At present, six-member countries of the Association of Southeast Asian Nations are the primary source of investment in China. Therefore, China and the other countries in the "Belt and Road" have massive room for import and export growth, which can cultivate new growth points in foreign trade. Chinese companies should actively conduct business with these countries. Besides, most of the countries along the "Belt and Road" are developing economies with poor infrastructure construction. China can use the "Belt and Road" to reduce production capacity and export infrastructure to solve China's overcapacity problem while expanding exports and deepening trade with countries along the line. In order to truly deepen the "Belt and Road," according to the free trade agreements or preferential trade arrangements signed by China and relevant countries or regions, China will continue to implement the agreed tax rates on some commodities originating in 23 countries or regions in 2020. Among them, China and New Zealand, Peru, Costa Rica, Switzerland, Iceland, Singapore, Australia, South Korea, Georgia, Chile, Pakistan, and the Asia-Pacific Trade Agreement have further reduced taxes. The tax reduction will directly promote the growth of bilateral trade volume and will be more conducive to sharing the results of the "Belt and Road" with other countries.

Besides, while actively cooperating in the economic and trade cooperation of the "Belt and Road" initiative, we should actively promote the reduction of non-tariff barriers. As non-tariff 
barrier measures are more concealed and diversified, countries along the "Belt and Road" should start from the following aspects: reduce barriers to customs clearance, ensure efficient completion of import links and customs procedures for goods; minimize import taxes and fees, and make the "Belt and Road" achievements benefit people of all countries; promote standardization and transparency of technology regulations and reduce technical barriers to trade in countries along the route.

Finally, it is necessary to cooperate with countries along the "Belt and Road" in innovative investment, promote cooperation in emerging industries, and develop characteristic trade. For example, China's traditional agriculture is facing a trend of rising prices due to the end of the demographic dividend period and often faces green trade barriers, and exports have become unmanageable. The aforementioned transparent standards for implementing technical regulations in countries along the "Belt and Road" will help China's agricultural product export standards meet the required standards and promote their exports. However, in the face of the problem of rising prices, we should also raise the level of agricultural science and technology and achieve large-scale operations, which will help improve the efficiency of agricultural output and ultimately reduce prices. Traditional agriculture should also take advantage of the Internet, actively expand ecommerce trade, vigorously promote its agricultural products, open up foreign markets, and take advantage of the "Belt and Road" opportunity to achieve a new integration of traditional agriculture with the Internet and high technology.

\section{Expand Trade with Neighboring Countries-Take China, Japan, And South Korea As An Example}

Based on the complementary industries between China and ASEAN, Japan, South Korea, and India, China can further promote the integration of regional industrial chains, regional supply chains, and regional value chains. Increasing the scale of trade with surrounding areas is conducive to closer economic and trade cooperation and is in line with China's current foreign trade status. This article will use China, Japan, and South Korea as examples to explore the feasibility and necessity of expanding trade between China and neighboring countries.

First, China and Japan and South Korea reached new diplomatic achievements in 2019 and achieved a new consensus on development. It provides an excellent platform for bilateral trade to a new level and increases the possibility of expanding trade scale. The conclusion of the RCEP negotiations marks a significant breakthrough in the construction of a free trade zone with 15 members that has the largest population in the world, the most diverse member structure, and the most significant development potential. This not only dramatically promotes trade between member countries, but also forms a useful supplement and good promotion to the world's multilateral trading system and mechanism, and is an effective solution to the downward pressure on the world economy today. As the principal members, China, Japan, and South Korea are staunch supporters of the negotiations and will directly benefit from the negotiations. China should take advantage of the excellent platform established by the RCEP to expand the scale of trade with Japan and South Korea, which is a powerful positive impact on reducing the economic weakness brought to China by the current complicated situation of Sino-US trade.

Secondly, China, Japan, and South Korea account for about $25 \%$ of the world's economy, and the three countries 'trade accounts for one-sixth of the world's total trade. They are all economies with excellent development potential and play an essential role in the world economy. Increasing the scale of trade between the three countries is a necessary measure to resolve the current weak state of the world economy. Besides, in the face of the different development stages of the three countries and the strong complementarity of the industries, it is also feasible to promote the expansion of the trade scale of the three countries. Therefore, the three parties should work together to promote the construction of the free trade zone, accelerate the implementation of the free trade zone agreement, and promote trade, investment facilitation, liberalization, and standardization. The three countries should also take advantage of the deep integration of their industrial and value chains, increase cooperation in scientific and technological innovation, maintain exchanges of 
talents, and support the two-way enterprises' two-way investment in new fields such as the Internet, big data, and artificial intelligence.

Finally, the three countries should work together to create new growth points in the service industry. As the world's largest developing country, China has a population of nearly 1.4 billion, and its population needs are diverse. And with the continuous development of the economy, the level of consumer consumption and demand has entered a new level, and China's service industry urgently needs to increase its high-quality supply. Therefore, strengthening the deepening of ChinaJapan-Korea cooperation in service trade will help the three countries cope with everyday social problems such as aging, realize a smooth transition in the period of economic weakness, and realize the complementary advantages of the three countries.

\section{Promote the Process of Establishing Free Trade Zones with Significant World Economies}

In the weak state of the world economy, the first part of the article analyzes that China's import and export trade with developed economies has entered a "bottleneck period." The old economic growth points have had a limited role in promoting the two economies, and new economic growth points have not yet been formed. Therefore, while further promoting the "Belt and Road" initiative, China should also focus on cultivating new growth points for trade with significant world economies.

The establishment of a free trade zone is an effective way to promote trade growth. At present, China has signed more than ten free trade agreements with more than 20 trading partners. This article uses three of China-Australia (signed in 2014), China-Peru (signed in 2010) and ChinaKorea (signed in 2012). Analysis of China's FTA partners and China's import and export data on different continents (see Figure 1). Observation of the data shows that although the signing of the FTA has promoted China's import and export trade to a certain extent. Since most of them are developing countries and emerging economies, their impact on trade is limited. Therefore, China should be committed to promoting negotiations on free trade zone agreements with significant world economies. This is also the experience learned from developed countries. Now that the United States, Japan, and Europe are competing to establish a bilateral or regional free trade agreement, the purpose is to increase their influence in the global trading system. China has clearly stated that "higher rules and regulations" are required to promote the development of high-quality trade. Some large and even giant free trade zones, such as CPTPP, are large-scale free trade agreements that cover the world's 498 million people, and the total GDP of member countries account for $13 \%$ of the global economy. Therefore, China can not only vigorously promote the full implementation of the RCEP agreement but also try to establish a comprehensive free trade agreement with Europe in the future. Cooperation with Europe has a track record in diplomatic relations in 2019. 2019 is a bumper year for Sino-European relations. Investment negotiations between the two sides have accelerated, and the Belt and Road cooperation have continued to progress. At the same time, it can be seen from Table 1 that the bilateral trade volume between China and the EU has shown a stable and progressive development trend. In the reality of the global economic downturn, it is not easy for China and the EU to maintain close economic and trade cooperation. 2020 is the 45th anniversary of the establishment of diplomatic relations between China and the EU. China and the EU should use this as an opportunity to carry out in-depth cooperation in the construction of a free trade zone and push China-EU comprehensive strategic partners to a new level.

To sum up, promoting the establishment of free trade area agreements with significant world economies is an effective measure to solve the lack of growth momentum in bilateral trade between China and significant developed country trading partners. In the current complicated situation of Sino-US relations, it is necessary to promote the establishment of a free trade zone will not only help China deepen its cooperation with trading partners and solve the economic downturn, but it will also make a significant contribution to the world economy, and it will be conducive to the continuous improvement and supplementation of multilateral cooperation mechanisms. 


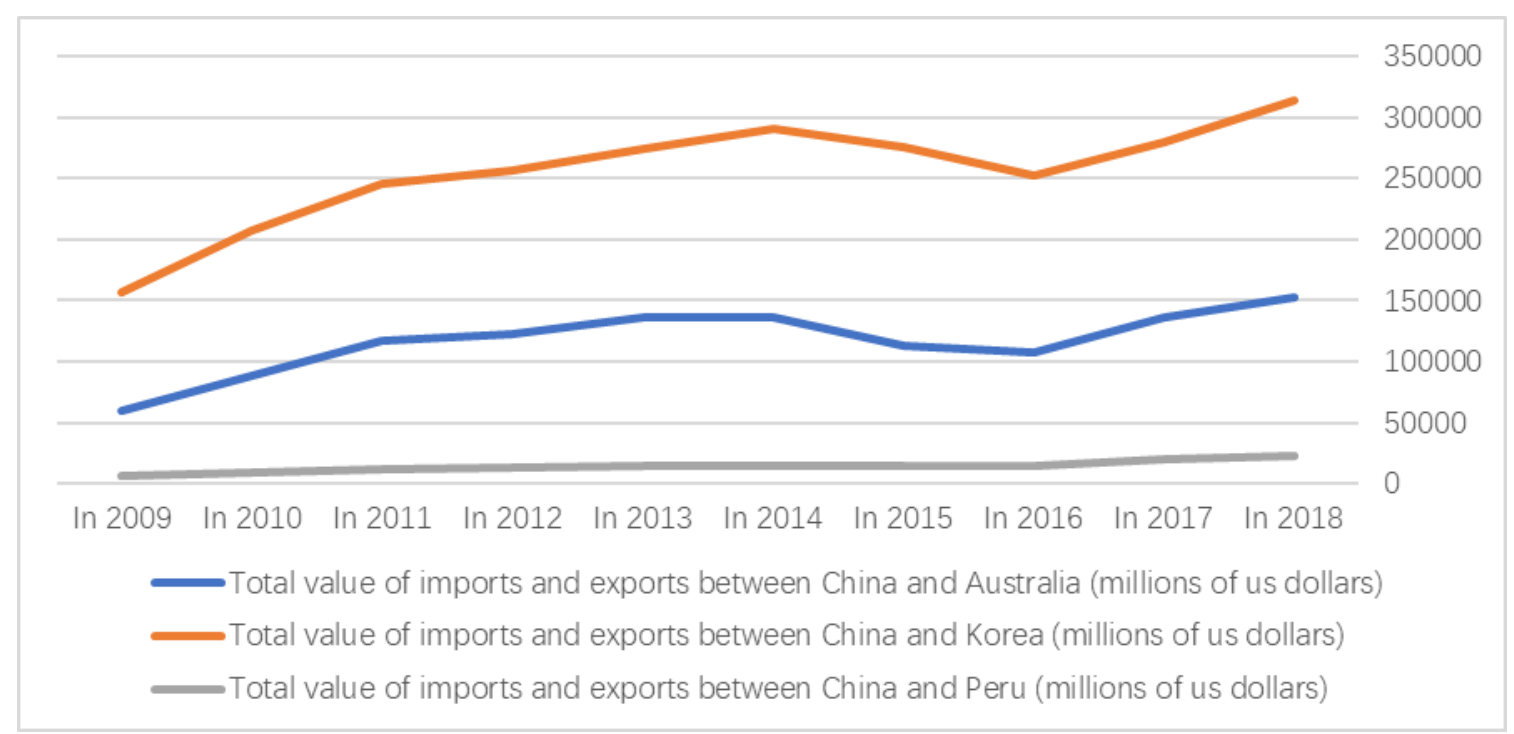

Figure 1 Trade impact of signing a free trade agreement

\section{Strengthen Risk Prevention in the Trade Field}

While promoting the high-quality development of trade, we must strengthen risk prevention in the trade field. Focusing on the prevention of risks in the trade field is to prevent problems before they occur, which is conducive to providing China with the necessary protection from a vast trading country to a strong one.

First of all, the government should actively respond to changes in international regulations, based on internationally accepted rules and advanced experiences of developed economies, plus real risks such as anti-dumping and anti-monopoly investigations that China has encountered in international trade practice since the reform and opening up. Experience, research, and formulate Chinese solutions with Chinese characteristics that are in line with the actual conditions of Chinese enterprises.

Secondly, because the level of the risk prevention system proposed by the government directly determines the level of government's controllability in the face of risks in the trade field, the government should effectively provide necessary guarantees for the international traffic of enterprises, that is, develop some defensive measures such as trade adjustment assistance System, which reduces the cost for enterprises in the face of trade frictions. It is of considerable significance to the international circulation of enterprises when they face trade frictions.

\section{Conclusion}

At present, China's trade has entered a significant period of transformation. The core goal of the trade field is no longer the pure pursuit of "quantity" breakthroughs such as the blowout growth of China's export-oriented enterprises in the early days of reform and opening up. Under the circumstances that the overall situation of world trade is not optimistic, China can start with primary trading partner countries, deeply integrate new formats such as the Internet and big data with the trade sector, and deepen its comprehensive strategic partnership with primary trading partner countries. The "Belt and Road" initiative has gone deep. Facing the current situation of increasing complexity in the trade field, the Chinese government should accelerate the improvement of the system of risk prevention, formulate a Chinese plan, and contribute to China's strength. China's economy is highly integrated with the world economy and is closely related. While using the Chinese program to promote the high-quality development of trade, it is also contributing to China's strength to the development of the world's multilateral economy and the improvement of the multilateral system. 


\section{References}

[1] Changzhu Li. Research on Development of College Physical Education under the Perspective of Sino-Russian Joint School-running, 2016 International Conference on Contemporary Education, Social Sciences and Humanities. 2016.

[2] Yi Liu, Jiawen Peng, and Zhihao Yu. 2018. Big Data Platform Architecture under the Background of Financial Technology: In the Insurance Industry as an Example. In Proceedings of the 2018 International Conference on Big Data Engineering and Technology (BDET 2018). ACM, New York, NY, USA, 31-35.

[3] Wang Keying. A Research on the Path of Development of the Cultural Industry of Tianjin: Based on the Perspective of Creative City Construction. Theory \& Modernization, 2013.

[4] JIA Jing-dun, WEI Xun, JIN Shu-qin. Development of Carbon-sinking Agriculture in Australia and its Enlightenment to China. Journal of Agricultural Science \& Technology, 2012, 14(2):7-11.

[5] Li Z, Bo S, Lu Q. The Research of Commercial Bank's Green Credit in China Based on the Threshold Effect, 2012.

[6] William R. Barnes. The uses of Urban Research: A Perspective on the Urban Observatory Experience. Real Estate Economics, 2(2):47-58.

[7] Zhang Yanjun, Yang Xiaodong, Liu Yi, Zheng Dayuan, Bi Shujun. Research on the Frame of Intelligent Inspection Platform Based on Spatio-temporal Data. Computer \& Digital Engineering, 2019, 47(03): 616-619+637. 